\title{
A COMPETENCE-BASED APPROACH TO TRAINING SPECIALISTS IN THE DIGITAL SOCIETY
}

\author{
Evgenia Liventsova*, Tatiana Rumyantseva, Ekaterina Syryamkina \\ National Research Tomsk State University, 634050, Tomsk, Russia
}

\begin{abstract}
The article analyzes the influence of digital technologies on transformation of the labor market in social services. Modern professions require workers with advanced digital skills as well as technical and engineering specialists with advanced soft skills. The article analyzes official documents and global trends in the future labor market and presents the experience of National Research Tomsk State University (TSU) in developing transprofessional skills of students in different specialties. The authors conclude that modern society and the labor market demand new forms and methods of education aimed to develop interdisciplinary competence.
\end{abstract}

\section{How digital technologies influence contemporary society}

Digital technologies are a set of processes that are based on the representation of signals by discrete bands of analog levels, but not in the form of a continuous spectrum [1]. In comparison with analog technologies, digital technologies allow you to transfer arrays of data easier and faster. Today, this type of technology is widely used in computers, robotics, and in digital computing electronics.

The President of the Russian Federation Vladimir Putin in his message to the Federal Assembly on December 1, 2016 noted that a new level of economic and social development requires focusing on areas where the powerful technological potential of the future is accumulated. These areas include digital and other breakthrough technologies, which now influence all spheres of life [2]. Therefore, digital technologies can be classified as breakthrough (cutting-edge), that is, those used in all sectors and in the social sphere as well.

Currently, information technologies cause active transformation of the society. New forms of interaction between the state and society, as well as between different groups of society greatly simplify certain processes and affect improvement of quality of life of people. For example, in the sphere of governmental social services, every citizen has an opportunity to share his problem in the online mode; and the representatives of the government services react online on these problems and submit reports on their resolutions. The on-line government services are becoming more popular; they allow getting necessary

* Corresponding author: evg.liv@mail.ru 
information and documents without queues and paperwork. The use of information technology also allows timely accumulation of civic activity, volunteer movements, and charitable organizations in order to solve certain social problems and provide more targeted assistance to a particular family, child, and other beneficiaries. Development of digital technologies improve quality of life of people with disabilities because of the emergence of new digital products that allow full integration into the society; these products include televisions with teletext for receiving programs with hidden subtitles, telephone devices with text output, voice-forming devices, special clothes, special devices for reading and much more.

Digital technologies significantly influence the sphere of education, which is now becoming increasingly mobile and accessible through dissemination of online learning. Scientists and engineers create special digital simulators and online learning programs, which allow people to get new knowledge and skills.

\section{New professions}

The long-term program of the Russian Federation, National Technology Initiative (NTI), adopted in 2015 [2], confirms the urgency of recognizing the transformation of society under the influence of new technologies. NTI is aimed to create conditions for ensuring leadership of Russian companies in the new high-tech markets that will determine the structure of the world economy in the next 15-20 years. However, developing new technologies demands new qualified specialists who can correctly apply these technologies. NTI defines nine markets of the future, and some of them are closely related to the social sphere. These include NeuroNet (a market for human-machine communications), HealthNet (a market for personalized medical services and medicines), and FoodNet (a market for production and sale of nutrients and final types of food products, as well as related IT solutions).

Key segments of NeuroNet's market include neuro-assistants, neuro-education, neuromedical devices, neuro-entertainment and sports, neuro-communications and marketing, and neuro-pharma. A key segment for HealthNet is information technology in medicine, which means design and implementation of devices for monitoring and correction of human health. FoodNet's market is mainly focused on intellectualization and automation of technological processes throughout the production cycle and is aimed at expanding the capacity to produce high-quality products. All the above-mentioned segments directly relate to the social sphere and demand not only developing new technologies but also new specialists who can work with these technologies.

In the rapidly changing conditions of modern life, not only IT professionals but also social workers need skills in digital technologies or the so-called digital skills. Prof. Dr. Edward V. Galazhinskiy, Rector of Tomsk State University, notes that "non-digital" professions (doctors, lawyers, actors, teachers of literature, and others) need digital skills in a standard package of competence because representatives of these professions are "members of the modern network digital society" [3].

We can better understand how specialists in the social sphere will apply digital skills if we analyze The Atlas of New Professions, developed and published by the Agency for Strategic Initiatives and the Skolkovo School of Management [4]. The Atlas describes new professions that will be in demand in the future and a list of transprofessional competencies that a "specialist of the future" should possess.

According to the Atlas, future professions in the social sphere will include that of a specialist in crowdsourcing societal problems, a social worker for the Internet-based adaptation of people with disabilities, a specialist in adaptation of immigrants, and a moderator of a platform for personal charitable programs. Education will demand 
coordinators of educational online platforms, mentors for startups, coaches for mind fitness, developers of educational trajectories, and developers of tools for teaching states of consciousness. These new professions will require such competencies as programming IT solutions, managing complex automated complexes, and working with artificial intelligence (Table 1).

Table 1. Future professions in social and educational spheres according to the Atlas of New Professions.

\begin{tabular}{|c|c|}
\hline Profession & Transprofessional competencies and skills \\
\hline Specialist in crowdsourcing societal problems & \multirow{7}{*}{$\begin{array}{l}\text { Programming IT solutions/ managing complex } \\
\text { automated complexes/ working with artificial } \\
\text { intelligence } \\
\text { Ability to manage projects and processes } \\
\text { Customer-oriented focus, ability to work with } \\
\text { customer requests } \\
\text { People skills (ability to interact with others) } \\
\text { Multilingual and multicultural development } \\
\text { Project management } \\
\text { System thinking }\end{array}$} \\
\hline $\begin{array}{l}\text { Social worker for the Internet-based adaptation } \\
\text { of people with disabilities } \\
\text { Specialist in adaptation of immigrants }\end{array}$ & \\
\hline $\begin{array}{l}\text { Moderator of platforms for personal charitable } \\
\text { programs }\end{array}$ & \\
\hline Coordinator of educational online platforms & \\
\hline Mentor for startups & \\
\hline Coach for mind fitness & \\
\hline Developer of educational trajectories & \\
\hline
\end{tabular}

On the contrary, if we refer to the section of the Atlas devoted to the IT sphere, we can find jobs directly related to the social sphere and requiring such transprofessional competencies as client-oriented work with people (Table 2). These are such future professions as an architect of information systems, interface designer, network lawyer, digital linguist, personal security consultant, and cyber-investigator. The tendency toward "society virtualization" is clearly identified: the virtual space will be organized according to the same principles as the national government. In this regard, there is a need to transfer some standard professions (such as lawyers, investigators, insurance agents, and others) to a virtual space.

Table 2. Future professions in IT-sphere according to the Atlas of New Professions.

\begin{tabular}{|l|l|}
\hline \multicolumn{1}{|c|}{ Profession } & \multicolumn{1}{|c|}{ Over-professional competency and skills } \\
\hline Architect of information systems, & $\begin{array}{l}\text { System thinking } \\
\text { Programming / Robotics / Artificial Intelligence } \\
\text { Customer orientation } \\
\text { Project management } \\
\text { Interface designer }\end{array}$ \\
$\begin{array}{ll}\text { Inter-industry communication } \\
\text { People skills (ability to interact with others) } \\
\text { Network lawyer }\end{array}$ & $\begin{array}{l}\text { Multilingual and multicultural development } \\
\text { Ability to work in conditions of uncertainty }\end{array}$ \\
\hline Personal security consultant & \\
\hline Cyber-investigator &
\end{tabular}




\section{Examples of educational programs and competitions to improve the social sphere by developing people's digital skills sponsored by Russian companies}

Speaking about opportunities for innovative creativity of young people, we can give some examples of programs organized by educational organizations in conjunction with socially responsible business. Let us consider an example of Rostelecom Company; it sets provision of social environment as one of the priorities of social policy. The company supports educational projects, develops new interactive programs and improves existing directions. The main attention in the company is paid to training of specialists in telecommunications, information security of university students and schoolchildren, as well as work on digital inequality. When developing educational projects, the company takes into account the interests of socially unprotected sections of the population [5].

Another example is the complex program of social investments "Native cities" realized by Gazprom Neft Company [6]. The program is aimed to increase the level of life of people in the cities, to create infrastructure for children and mass sports, and to implement initiatives in the field of culture, health and education. According to the program regulations, non-profit organizations, universities, social institutions, and even initiative groups of citizens can participate in the program. The competition is aimed at finding ways to solve problems of society or certain social groups.

Since 2017, a special nomination Digital Technologies has been allocated within the framework of the "Native cities" program [6]. The nomination includes internet projects (portals, services), applications /services for mobile devices and other gadgets, games using virtual and /or augmented reality technologies, digital-installation, interactive modules, multi touch technologies; digital technology-based projects and activities; and video campaigns.

Appearance of this nomination is associated with the successful experience of the Federal Competition of Social Projects "People Need You" organized by St. Petersburg National University of Information Technologies, Mechanics and Optics [7, 8].

This competition represents a mechanism for stimulating creativity of students in the field of social design and entrepreneurship and developing students' skills in project management that can be successfully used in future social and professional activities.

\section{Experience of National Research Tomsk State University (TSU)}

Program of TSU strategic development as a national research university ${ }^{\dagger}$ for $2010-2019$ highlights social and humanistic knowledge and technologies as one of the main direction in modernization of the economy and the social sphere. Moreover, among provincial universities with the status of national research university, only TSU has announced humanistic studies as one of the priority research areas. Based on the great experience of training specialists in humanities and taking into account global trends Tomsk State University has started to pay more attention to developing soft skills of all students including students of engineering and technical specialties. This includes ability for effective team communication, learning of the basic principles of behavior on the labor market, and business activity in the social sphere, which leads to the development of interpersonal skills, system thinking, formation of an active lifestyle and professional positions.

\footnotetext{
$\dagger$ In 2010, TSU became a winner in the federal competition between Russian universities and gained a status of National Research University.
} 
Realizing that the concepts of innovation potential and entrepreneurial resource are closely connected with the individual's creativity, TSU has created a structural unit - the Park of Social and Humanistic technologies (hereinafter, the Park) aimed to implement the above-mentioned technologies of work with students of both humanities and engineering sciences [9]. Another aim of the Park is to involve students in social and entrepreneurial activity, as well as to attract professional experience of members of the local community to the university $[10,11]$.

The Park's goal is to organize environment for innovative development of university students in order to enhance humanistic technologies and social entrepreneurship. Therefore, the Park's activities include commercialization of social innovative projects, involvement of students and employees of TSU in creation, development and implementation of innovative social projects, involvement of TSU students and employees in entrepreneurial activities, and coordination of interaction between society, government and business organizations. During 2012-2015, the Park has implemented the strategy for developing entrepreneurial competencies of students of various specialties.

Table 3 shows annual events of the Park.

Table 3 Annual events of the Park of Social and Humanistic Technologies of TSU.

\begin{tabular}{|c|c|}
\hline Events of the Park & $\begin{array}{c}\begin{array}{c}\text { Transprofessional skills and competencies } \\
\text { developed }\end{array} \\
\end{array}$ \\
\hline $\begin{array}{l}\text { Competition of creative ideas "Student's } \\
\text { Tomsk" (selection and assistance in } \\
\text { implementing students' creative ideas aimed to } \\
\text { improve the university and the city } \\
\text { environment) }\end{array}$ & $\begin{array}{l}\text { Creative thinking } \\
\text { People skills (ability to interact with others) } \\
\text { Ability to work in a team }\end{array}$ \\
\hline $\begin{array}{l}\text { Special educational program for training social } \\
\text { and entrepreneurial skills of students }\end{array}$ & $\begin{array}{l}\text { Skills for entrepreneurship in social sphere } \\
\text { System thinking }\end{array}$ \\
\hline $\begin{array}{l}\text { Competition of social projects "Important } \\
\text { Deal" (selection and assistance in the } \\
\text { implementation of social and entrepreneurial } \\
\text { projects of schoolchildren and students aimed } \\
\text { to solve problems existing in social sphere) }\end{array}$ & $\begin{array}{l}\text { Ability to work in a team } \\
\text { Project management } \\
\text { People skills (ability to interact with others) }\end{array}$ \\
\hline $\begin{array}{l}\text { Social and investment exhibition "Important } \\
\text { Deal" } \\
\text { (presentation of projects /products to the } \\
\text { representatives of business and city authorities) }\end{array}$ & $\begin{array}{l}\text { Skills of product /project presentation } \\
\text { Skills of self-presentation } \\
\text { Communication skills }\end{array}$ \\
\hline $\begin{array}{l}\text { Intensive educational program "StartUpSocial" } \\
\text { for acceleration of students' entrepreneurial } \\
\text { projects in the social sphere }\end{array}$ & $\begin{array}{l}\text { Skills for entrepreneurial activities in the social } \\
\text { sphere } \\
\text { Ability to work in a team } \\
\text { Project management } \\
\text { People skills (ability to interact with others) } \\
\text { Programming skills }\end{array}$ \\
\hline $\begin{array}{l}\text { Business Club of the Park of social and } \\
\text { humanitarian technologies of TSU } \\
\text { (monthly discussions between students, } \\
\text { representatives of business, government, NGOs } \\
\text { and educational institutions) }\end{array}$ & $\begin{array}{l}\text { Development of system thinking } \\
\text { Communication skills }\end{array}$ \\
\hline $\begin{array}{l}\text { Program of additional education "TSU } \\
\text { Students are Specialists of the Future" (a new } \\
\text { program launched in 2017) }\end{array}$ & $\begin{array}{l}\text { System thinking } \\
\text { Critical thinking } \\
\text { Digital skills }\end{array}$ \\
\hline
\end{tabular}




\section{Conclusion}

Rapid development of technology leads to transformation of society and change of the labor market and demand renewal of educational approaches as well as integration of information and innovative methods of education.

The totality of the abovementioned forms of educational technology allows motivating students to obtain new professional skills because it is important for a student to identify the result of his education as a set of professional knowledge and skills, which can be successfully applied in practice and will allow being competitive on the labor market.

Today, university graduates need transprofessional skills; and an important fact is that these skills can be gained within the curriculum if universities organize additional programs of professional training for students of various specialties. These programs will have greater effect if they are implemented based on deep analysis of the current situation and future trends of the labor market and in close cooperation with partner-organizations.

The competence-based approach (orientation to transprofessional competences) may facilitate overcoming a lag between the theoretical training of students within the basic university curriculum and practical experience because any activity loses sense if it does not meet the needs of a contemporary society.

\section{Acknowledgements}

The research presented in this paper was supported by the Russian Foundation for Basic Research (grant No 16-29-04388/17).

\section{References}

[1] NTI Dictionary URL: http://www.nti2035.ru/nti/reference/

[2] The President's Address to the Federal Assembly URL: http://kremlin.ru/events/president/news/53379

[3] Triumvirate «skills» as a formula of demand for a university graduate URL: http://www.tsu.ru/university/rector_page/triumvirat-skillz-kak-formulavostrebovannosti-vypusknika-vuza/

[4] The Atlas of new professions URL: http://atlas100.ru/

[5] Principles and priorities of social policy URL: http://www.rostelecom.ru/social/politics/

[6] Grant Competitions of social initiatives URL: http://www.grant.rodnyegoroda.ru

[7] Regulations on the Federal competition of social projects «People need you!» URL: http://socialprojectspb.ru/wp-content/uploads/2017/02/regulations_tnl-2017.pdf

[8] Expanding the reach and impact of the humanities for the public good URL: http://www.cdh.ucla.edu

[9] Park of Social and Humanitarian Technologies of Tomsk State University URL: http://parksgt.tsu.ru

[10] The Fourth Industrial Revolution URL: $\quad$ https://www.foreignaffairs.com/articles/2015-12-12/fourth-industrialrevolution

[11] Youth social entrepreneurship advancing the field URL: http://www.sundancefamilyfoundation.org/yse-toolkit/yse-white-paper 